\title{
A Visible Record of Eddies in the Southern Mozambique Channel
}

\author{
Graham D. Quartly \& Meric A. Srokosz \\ Laboratory for Satellite Oceanography \\ Southampton Oceanography Centre \\ Southampton, UK \\ <gdq@soc.soton.ac.uk>
}

\begin{abstract}
The flows around Madagascar feed into the Agulhas Current, but there have been few hydrographic studies of the flow within the Mozambique Channel. Some cruise and altimetric data point to this being a region of high mesoscale activity, with eddies migrating through the area. Here we show how ocean colour data throw light on the behaviour of eddies in the southern Mozambique Channel.
\end{abstract}

Keywords - eddies; retroflection; chlorophyll concentrations; feature-tracking; Madagascar; Mozambique Channel

\section{INTRODUCTION}

The southern Indian Ocean circulation includes the westward-flowing Southern Equatorial Current (SEC) at $15^{\circ}$ $20^{\circ} \mathrm{S}$. This water flows both north and south of Madagascar (Fig. 1a), with much of the water subsequently heading poleward in the Agulhas Current, the strongest southern hemisphere western boundary current. Moorings to the east and north of Madagascar show continuous flow [1], but observations in the Mozambique Channel and to the south of Madagascar have found intermittent flow, with occasional flow reversals. Drifter tracks [2] and satellite imagery [3-6] have suggested the existence of a retroflecting current south of Madagascar, similar to the Agulhas Retroflection some 2000 $\mathrm{km}$ to the southwest. Shedding of eddies from this retroflection would be consistent with the many eddies found in hydrographic surveys further south [7,8]. A recent cruise found a number of anticyclonic eddies on the western edge of the Mozambique Channel [9], with moorings across the narrowest point of the channel at $17^{\circ} \mathrm{S}$ indicating the generation / southward progression of eddies at the rate of about 4-5 per year [10]. Here, using SeaWiFS ocean colour data, we examine such features, which have been made visible by eddies distributing coastal chlorophyll-rich waters into the middle of the channel.

\section{DATA AND PROCESSING}

The data are the chlorophyll concentrations (CC) derived from the SeaWiFS (Sea-Viewing Wide Field-of-View Sensor), provided by NASA/GSFC on a $9 \mathrm{~km} \times 9 \mathrm{~km}$ grid. These data are composited into 6-day periods (hexads), with some smoothing to reduce the effect of persistent cloud cover. Details on the processing are given in [11]. The annual mean CC (Fig. 1b) shows much higher values along the coast than mid-channel, with pronounced values in the Delagoa Bight, along the Banco de Sofala and immediately south of Madagascar. The entrainment of the higher CC coastal waters by eddies in the channel enables us to study their progression and other properties (such as sense of rotation).
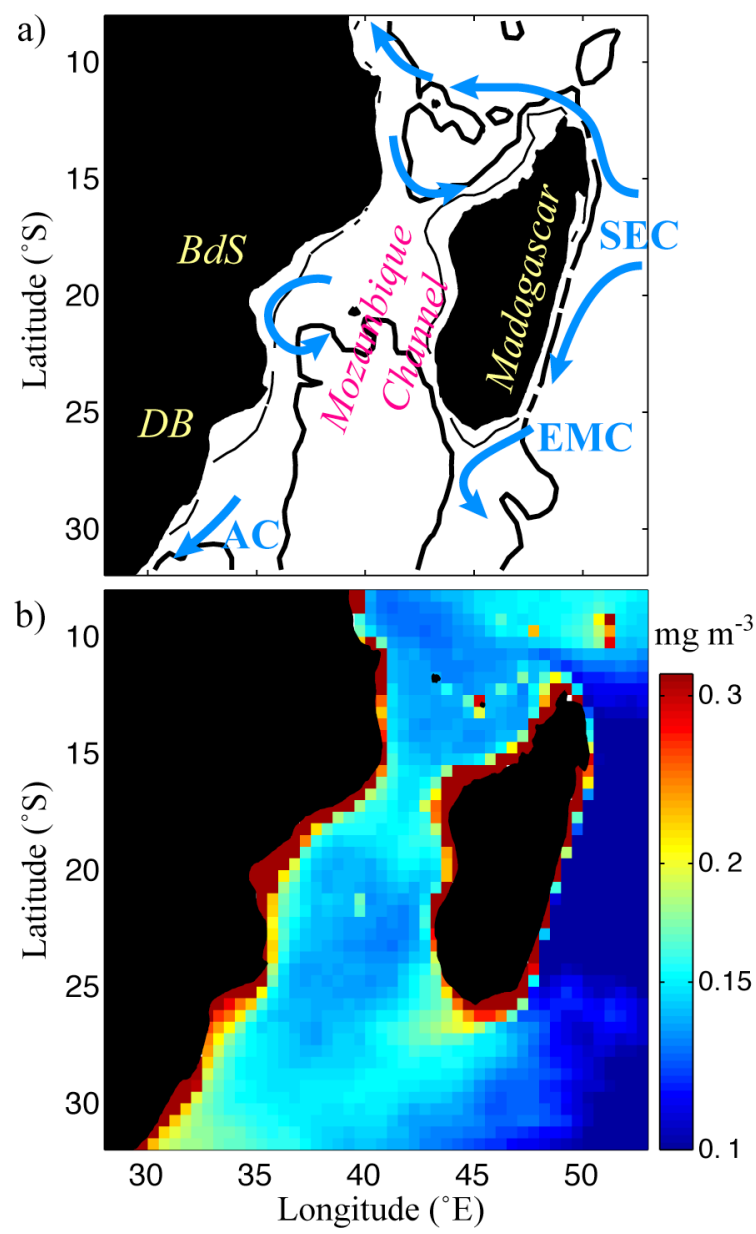

Figure 1. a) Schematic of the flow around Madagascar with the $3000 \mathrm{~m}$ (thick) and $1000 \mathrm{~m}$ (thin) isobaths marked. (SEC - Southern Equatorial Current; EMC - East Madagascar Current; AC - Agulhas Current; BdS Banco de Sofala; DB - Delagoa Bight.). b) Mean chlorophyll concentration (averaged over 4 years). 


\section{Chlorophyll concentration $\left(\mathrm{mg} \mathrm{m}^{-3}\right)$}
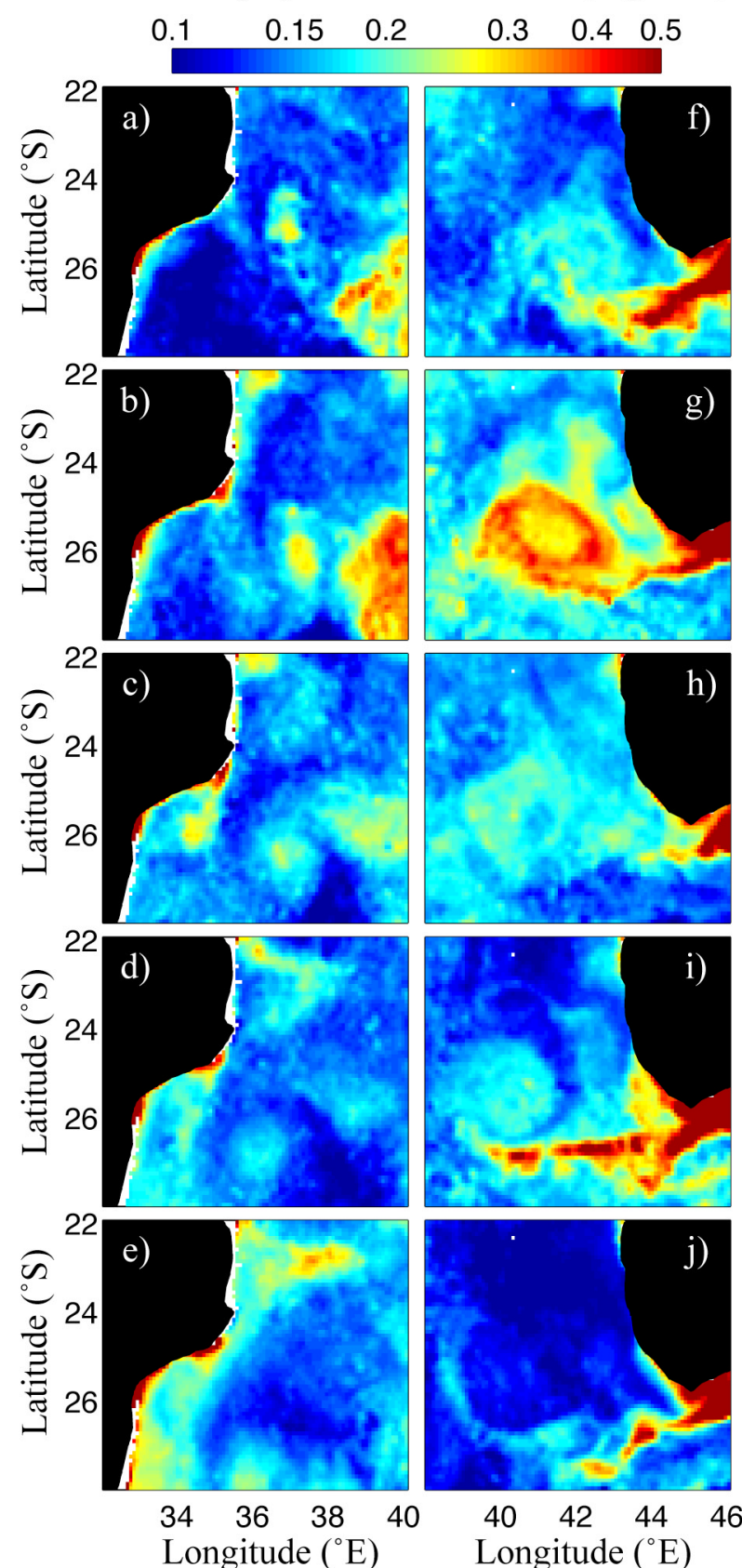

Figure 2. Sequences of 6-day composites of chlorophyll concentration. [Images are at intervals of 12 or 18 days.]. a-e) Anticyclonic eddy moving south along western edge of the Mozambique Channel April-May 2002). f-j) Cyclonic eddy leaving the lee of southern Madagascar and travelling westward across the channel (Sept.-Oct. 2002).

\section{EDDY PROPAGATION}

Fig. 2a-e shows the southward progression of an eddy (starting at $37^{\circ} \mathrm{E}, 25^{\circ} \mathrm{S}$ ) during April-May 2002. Its anticyclonic rotation is revealed by the swirl of high $\mathrm{CC}$ water entrained from the coast. In Fig. 2e a southward strand of increased CC remains at $34^{\circ} \mathrm{E}, 26^{\circ} \mathrm{S}$, indicative of clockwise circulation on the shelf, associated with the Delagoa Bight eddy, a near permanent feature of the region [12]. The passage of anticyclonic eddies beyond the shelf edge may help maintain the clockwise circulation on the shelf, or just improve its visual identification by enhancing the entrainment of high $\mathrm{CC}$ waters. At $23^{\circ} \mathrm{S}$ in Fig. 2e, a tongue of high $\mathrm{CC}$ water can be seen stretching out into the channel, caused by the next anticyclonic feature moving south into the region.

Figures $2 \mathrm{f}-\mathrm{j}$ shows the development of a very different feature. A large cyclone lies just west of the southern tip of Madagascar, with the eddy wrapping itself in the high $\mathrm{CC}$ coastal waters. The feature cannot be detected earlier than Fig. $2 \mathrm{f}$. It is not clear whether the eddy forms in the lee of Madagascar, or whether the eddy has drifted there and only then become visible in ocean colour data. Other images [11] suggest the latter is the case, at least sometimes.

\section{RETRO-FICTION?}

The East Madagascar Current (EMC) can be distinguished from neighbouring water masses by its higher temperature and low CC. These properties can be used to follow the EMC beyond the southern tip of Madagascar, and, in particular, address the supposed existence of an East Madagascar Retroflection. A recent hydrographic survey has shown the EMC sometimes penetrates deeper than 2000m; thus the shallow ridge south of Madagascar will provide some impediment to the passage of currents over it. Several authors [3-6] have shown satellite imagery similar to Figs. 3c,d, which is suggestive of a retroflection. However, an animation of composites spanning the period shown [11] shows an anticyclonic eddy-like feature moving in 60 days from $49^{\circ} \mathrm{E}$, $29^{\circ} \mathrm{S}$ in Fig. $3 \mathrm{a}$ to $46^{\circ} \mathrm{E}, 28^{\circ} \mathrm{S}$ in Fig. $3 \mathrm{~d}$, and then continuing southwestward. Other images (not shown) suggest this happens on a number of occasions; consistent with altimetric analysis [13] and high-resolution model results [14].

\section{SUMMARY}

Although $\mathrm{CC}$ is non-conservative tracer, it can throw light on complex physical systems. SeaWiFS data for the southern Mozambique Channel show anticyclonic eddies moving southward along its western edge and interacting with the circulation in the Delagoa Bight. The frequency of events passing southward through this region is about 4-5 per year, consistent with the rate reported for the line of moorings across the narrowest point of the Mozambique Channel [10]. On the eastern edge large cyclonic eddies exist, which move west or west-southwestward. The issue of whether they are created in the lee of Madagascar or have migrated southward along the Madagascar coast is yet to be fully resolved. Although ocean colour data were originally used to support the existence of an East Madagascar Retroflection, this now appears to be a fiction, with a series of anticyclonic eddies in the East Madagascar Current providing an alternative explanation.

\section{ACKNOWLEDGMENTS}

Data were provided by the SeaWiFS Project and the Distributed Active Archive Center at NASA/GSFC through the 'Mission to Planet Earth' program. 


\section{REFERENCES}

[1] F. Schott, M. Fieux, J. Kindle, J. Swallow, and R. Zantopp, "Boundary currents east and north of Madagascar. 2. Direct measurements and model comparisons,” J. Geophys. Res., vol. 93, pp. 4963-4974, 1988.

[2] J. R. E. Lutjeharms, N. D. Bang, and C. P. Duncan, "Characteristics of the currents east and south of Madagascar," Deep Sea Res., vol. 28A, pp. 879-899, 1981.

[3] J. R. E. Lutjeharms, "Remote sensing corroboration of retroflection of the East Madagascar Current," Deep Sea Res., vol. 35, pp. 2045-2050, 1988.

[4] J. R. E. Lutjeharms, and E. Machu, "An upwelling cell inshore of the East Madagascar Current,” Deep Sea Res., vol. 47, pp. 2405-2411, 2000.

[5] S. F. di Marco, P. Chapman, and W. D. Nowlin, "Satellite observations of upwelling on the continental shelf south of Madagascar," Geophys. Res. Lett., vol. 27, pp. 3965-3968, 2000.

[6] G. D. Quartly, and M. A. Srokosz, "Satellite observations of the Agulhas Current system,” Phil. Trans. Roy. Soc. London, vol. A361, pp. 51-56, 2003

[7] M. L. Gründlingh, "An intense cyclonic eddy east of the Mozambique Ridge,” J. Geophys. Res., vol. 90, pp. 7163-7167, 1985.

[8] M. L. Gründlingh, R. A. Carter, and R. C. Stanton, "Circulation and water properties of the southwest Indian Ocean, spring 1987," Prog. Oceanogr., vol. 28, pp. 305-342, 1991.

[9] W. P. M. de Ruijter, H. Ridderinkhof, J. R. E. Lutjeharms, M. W. Schouten, and C. Veth, "Observations of the flow in the Mozambique Channel,” Geophys. Res. Lett., vol. 29 (10), pp. 140:1-4, 2002.

[10] H. Ridderinkhof, and W. P. M. de Ruijter, "Moored current observations in the Mozambique Channel," unpublished.

[11] G. D. Quartly, and M. A. Srokosz, "Eddies in the southern Mozambique Channel," Deep Sea Res. II., in press.

[12] J. R. E. Lutjeharms, and A. Jorge da Silva, "The Delagoa Bight eddy," Deep Sea Res., vol. 35, pp. 619-634, 1988.

[13] M. W. Schouten , W. P. M. de Ruijter, P. J. van Leeuwen, and H. Ridderinkhof, "Eddies and variability in the Mozambique Channel," unpublished.

[14] A. Biastoch, and W. Krauss, "The role of mesoscale eddies in the source region of the Agulhas Current," J. Phys. Oceanogr., vol. 29, pp. 23032317,1999

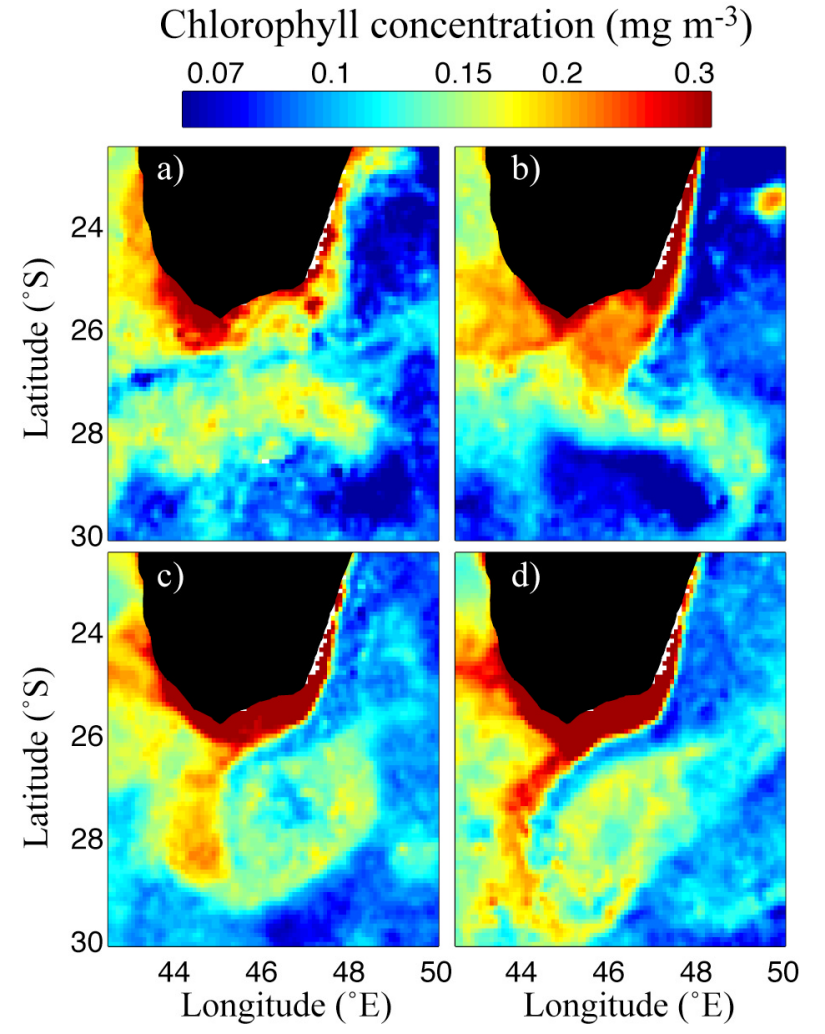

Figure 3. Sequence of images finishing with the appearance of an apparent EMC retroflection. (Images are 6-day composites at 12- or 18-days separation, taken from April-June 2001.) 